NAAT methods. All the specimens were tested by Versant CT/ GC DNA 1.0.

In case of a Versant CT positive result, we collected the corresponding remnant DNA extract and used it as a template for omp1 semi-nested-PCR. RFLP analysis of PCR-positive samples was carried out by using AluI, HinfI and DdeI as restriction enzymes, for genotyping.

All the specimens scored GC positive were retested by a "homemade" PCR assay, targeting cppB gene.

Results A total of 253 samples were obtained. In particular, we tested 14 conjunctival swabs, 155 pharyngeal swabs and 84 rectal swabs.

Versant assay scored as GC positive 13 pharyngeal and 7 rectal samples. All these specimens were confirmed reactive by cppB PCR. Regarding CT infections, Versant assay identified 2 ocular specimens as positive: one was further genotyped as $\mathrm{E}$ and the other one as F. Moreover, we found 4 positive pharyngeal specimens (genotypes E, F, J) and 12 rectal samples (genotypes E, H, J, L2).

Conclusions Versant CT/GC DNA 1.0 demonstrated to be a very good method to identify extra-genital infections due to chlamydia and/or gonorrhoea. Because of its performances, and the walk-away capability of the system, this assay can be considered an excellent choice for CT/GC diagnosis.

\section{P5.087 EVALUATION OF THE MULTIPLEX AMPLISENS HCV/HBV/ HIV-FRT REAL-TIME PCR FOR SIMULTANEOUS QUALITATIVE DETECTION OF HEPATITIS C RNA, HEPATITIS B DNA AND HIV RNA}

doi:10.1136/sextrans-2013-051184.1131

'K Malm, 'M Unemo, 'S Thulin Hedberg, ${ }^{2} \mathrm{D}$ Kireev, 'S Andersson. 'Dept of Laboratory Medicine, Örebro, Sweden; ${ }^{2}$ Central Research Institute for Epidemiology, Moscow, Russian Federation

Background Human donors of tissues and organs are obliged to undergo analysis for several blood transmitted infections. Serological assays are used, but for ideal sensitivity particularly for early infections these assays are beneficially supplemented with a nucleic acid amplification test (NAAT). For this as well as other diagnostic purposes, we have evaluated the multiplex AmpliSens HCV/HBV/ HIV-FRT real-time PCR for simultaneous qualitative detection of HCV RNA, HBV DNA and HIV RNA in clinical plasma samples.

Methods Clinical plasma samples with known concentrations (according to viral load assays from Roche Diagnostics) of HCV $\left(\mathrm{n}=34\right.$; range: $\left.25-4.9 \times 10^{6} \mathrm{IU} / \mathrm{mL}\right), \mathrm{HBV}\left(\mathrm{n}=30 ; 20-7.6 \times 10^{4} \mathrm{IU} /\right.$ $\mathrm{mL})$ and HIV $\left(\mathrm{n}=32 ; 34-4.7 \times 10^{5} \mathrm{c} / \mathrm{mL}\right)$; and samples from virusnegative blood donors $(n=100)$ were tested. Nucleic acid was isolated from $1 \mathrm{~mL}$ plasma on the MagNA Pure Compact using its Total Nucleic Acid Isolation kit I-Large Volume (Roche Diagnostics). The multiplex AmpliSens HCV/HBV/HIV-FRT real-time PCR (Central Research Institute of Epidemiology, Moscow, Russia) was run on a Rotor-Gene Q PCR instrument (Qiagen).

Results To date, 96 samples with various viral loads of HCV $(\mathrm{n}=34), \mathrm{HBV}(\mathrm{n}=30)$ and HIV $(\mathrm{n}=32)$, have been analysed. Only three samples with very low concentrations of HCV (<25-59 IU/ $\mathrm{mL}$ ) were false negative, and no false positive samples have been found. Complete data of the study will be presented at the meeting. Conclusion The multiplex AmpliSens HCV/HBV/HIV-FRT realtime PCR proved to be highly sensitive and specific. Accordingly, this rapid, technically simple and low cost assay might be effectively used for screening of human donors as well as for other diagnostic purposes

\section{P5.088 CHLAMYDIA TRACHOMATIS AND NEISSERIA GONORRHOEA DIAGNOSIS BY NUCLEIC ACID AMPLIFICATION TESTS AMONG FEMALE ENTERTAINMENT WORKERS (FEWS) IN CAMBODIA}

doi:10.1136/sextrans-2013-051184.1132
J R Papp, ${ }^{2} \mathrm{M}$ Chandara, ${ }^{2} \mathrm{M}$ Phalkun, ${ }^{1} \mathrm{C}$ Phillips, ${ }^{1} \mathrm{C}$ Farshy, ${ }^{3} \mathrm{C}$ Hy, ${ }^{3} \mathrm{M}$ Downer, ${ }^{2} \mathrm{M}$ Vun, ${ }^{3}$ W Killam. ${ }^{1} \mathrm{CDC}$, Atlanta, GA, United States, ${ }^{2} \mathrm{NCHADS}$, Phnom Penh, Cambodia, ${ }^{3} \mathrm{CDC}$, Phnom Penh, Cambodia

Background Accurate diagnosis of chlamydia and gonorrhoea infections followed by appropriate treatment are critical steps in preventing transmission and morbidity. Sex workers are a target population for lab-based screening. This study compared the performance of commercially available nucleic acid amplification tests (NAATs) to detect chlamydia and gonorrhoea infections among FEWs in Cambodia.

Methods In 2011, 2564 FEWs were recruited and consented into a national prevalence survey for sexually transmitted infections (STIs) in Cambodia. Two self-collected vaginal swab specimens were obtained from 2525 FEWs. One swab was placed in m2000 media for testing with m2000, and the other was placed in GeneLock media for testing with AC2 and GeneXpert. Specimens were tested for chlamydia and gonorrhoea with the Abbott m2000 and Aptima AC2 assays. Samples with discrepant results were tested with the Cepheid GeneXpert assay. The reference standard was defined as results from two of three assays being in agreement.

Results By reference standard, chlamydia and gonorrhoea were detected in $21.2 \%$ and $7.0 \%$ of samples respectively. The m2000 and AC2 assays detected chlamydia in 499 specimens, and discordant results were found in 127 specimens. When compared to the reference standard, the m2000 sensitivity and specificity for chlamydia was $99.1 \%$ and $95.8 \%$ respectively. The sensitivity and specificity of AC2 for chlamydia was $94.4 \%$ and $99.6 \%$. Gonorrhea was detected by both assays in 134 specimens while 110 yielded discordant results. The $\mathrm{m} 2000$ was $97.7 \%$ and $97.3 \%$ sensitive and specific for gonorrhoea while sensitivity and specificity of AC2 was $78.0 \%$ and $99.9 \%$ respectively.

Conclusions Chlamydia and gonorrhoea are prevalent STIs among Cambodian FEWs. Both NAATs had high sensitivity and specificity for chlamydia, and high specificity for gonorrhoea, but the AC2 sensitivity for gonorrhoea was low. Given high sensitivity and specificity of the assays, cost and usability will be important factors for ongoing programmatic use.

\section{P5.089 CONFIRMATION OF HIGH SPECIFICITY OF AN AUTOMATED ELISA TEST FOR SEROLOGICAL DIAGNOSIS OF SYPHILIS - RESULTS FROM CONFIRMATORY TESTING AFTER SYPHILIS SCREENING AND SENSITIVITY ANALYSIS IN THE ABSENCE OF A GOLD STANDARD}

doi:10.1136/sextrans-2013-051184.1133

1,2L van Dommelen, ${ }^{3,4,2} \mathbf{C}$ J P A Hoebe, ${ }^{1,2} \mathrm{~F} \mathrm{H}$ van Tiel, ${ }^{1,2} \mathrm{C}$ Thijs, ${ }^{1,2 \mathrm{~V} J}$ Goossens, ${ }^{1,2} \mathrm{C}$ A Bruggeman, ${ }^{1,2}$ H M van Loo. ${ }^{1}$ Maastricht University Medical Centre, Maastricht, The Netherlands; ${ }^{2}$ CAPHRI School of Public Health and Primary Care, Maastricht, The Netherlands; ${ }^{3}$ Public Health Service South Limburg, Geleen, The Netherlands; ${ }^{4}$ Maastricht University Medical Centre, Maastrich, The Netherlands

Background In clinical microbiology laboratories, serological diagnostic assays are usually implemented after evaluation using a selected sample collection. We have previously evaluated the performance of the Bioelisa Syphilis 3.0 compared with the Treponema pallidum Particle Agglutination (TPPA) in a selected collection of serum samples (syphilis positivity rate 44\%) and found a sensitivity and specificity of both $100 \%$. In the current study we have compared the specificity of Bioelisa Syphilis 3.0 after clinical implementation as a syphilis screening test with the specificity found in the previous evaluation to assess whether the high specificity would stand up in clinical practise.

Methods We included 14,622 sera (positivity rate $0.9 \%$ ) sent to the laboratory for syphilis serology in the period between October 2007 and February 2010. 